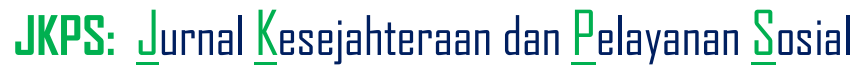

ISSN: 2716-3857 (Online)

\begin{tabular}{l|l|l|l|l|}
\hline Volume 2 & Nomor 2 & Nov (2021) & DOI: http://dx.doi.org/10.52423/jkps.v2i2.20588 & $172-183$ \\
\hline
\end{tabular}

\title{
Kebijakan Program Kartu Prakerja Dalam Mengurangi Pengangguran Di Masa Pandemi Covid-19
}

\author{
Nikmatul Choyroh Pamungkas ${ }^{1}$ \\ ${ }^{1}$ Universitas Islam Negeri Sunan Kalijaga Yogyakarta, Indonesia \\ *Korespondensi: Nikmatulchoyroh99@gmail.com
}

\begin{abstract}
Abstrak: Pandemi covid-19 berdampak pada perekonomian di Indonesia dari karyawan dirumahkan, PHK dan pengurangan pendapatan bagi mereka yang bekerja. Permasalahn tersebut membuat tingkat pengangguran semakin tinggi daripada tahun sebelumnya, maka pemerintah secara cepat membuat kebijakan untuk mengurangi tingkat pengangguran di Indonesia. Kebijakan tersebut adalah program kartu prakerja yang difokuskan kepada mereka yang telah kehilangan pekerjaan atau pengurangan penghasilan selama masa pandemi covid-19 ini. Tujuan penelitian ini yaitu untuk mengetahui bagaimana kebijakan program kartu prakerja memperdayakan masyarakat untuk mengurangi pengangguran. Penelitian ini menggunakan metode literatur review dimana sumber dari beberapa jurnal dan data yang di olah menjadi deskriptif. Dalam artikel ini juga menghasilkan bahwa kebijakan program kartu prakerja mebantu memberikan intensi bagi peserta yang lolos dan dapat mengikuti pelatihan yang disediakan sesuai dengan keadaan saat ini. Pelatihan tersebut diharapkan dapat membantu membangun perekonomian karena pelatihan tersebut dapat membuka lapangan pekerjaan bagi mereka yang mengikuti program kartu pra kerja yang di sediakan pemerintah.
\end{abstract}

Kata-kata kunci: Kebijakan, program prakerja, pengangguran

Abstract: The COVID-19 pandemic has had an impact on the economy in Indonesia from employees being laid off, layoffs, and reduced income for those who work. This problem made the unemployment rate higher than the previous year, so the government quickly made policies to reduce the unemployment rate in Indonesia. The policy is a preemployment card program that is focused on those who have lost their jobs or reduced their income during pandemic COVID-19. The purpose of this study is to find out how 
the pre-employment card program policy empowers the community to reduce unemployment. This study uses a literature review method were sources from several journals and data are processed to be descriptive. This article showing that the preemployment card program policy helps provide intentions for participants who pass and can take part in the training provided according to current conditions. The training expected to help build the economy because the training can create job opportunities for those who take part in the pre-employment card program provided by the government.

Keywords: Policy, pre-employment program, unemployment.

\section{Pendahuluan}

Indonesia merupakan negara kepulauan dan negara yang memiliki penduduk yang cukup banyak, banyaknya penduduk yang dimiliki negara Indonesia maka akan timbulnya banyaknya permasalahan yang terjadi. Namun permasalahan tersebut selalu ada solusi yang di manfaatkan untuk keluar dari suatu permasalahan tersebut. Pada awal tahun 2020 Indonesia banyak mengalami bencana alam baik dari banjir, putting beliung, tanah longsor, erupsi gunung Merapi, gelombang pasang atau absari, kebakaran hutan dan pada awal tahun 2020 Indonesia juga di kagetkan dengan wabah virus corona atau covid-19 yang tersebar hampir diseluruh Dunia. Dimana virus tersebut bermula dan terdeteksi di negara Wuhan, China pada bulan Desember 2019 dan mulai tersebar keberbagai penjuru dunia. Virus tersebut diduga ditumbulkan penyebaran melalui hewan ke manusia dan selanjutnya dari manusia ke manusia, selanjutnya kasus semakin meningkat dari hari ke hari petugas medis pun terkena infeksi covid-19 (Setiawati, Sariti, and Livana 2020).

Gejala bagi yang terinfeksi covid-19 ini meliputi demam, batuk kering, kelelahan, anosmia (kehilangan bau), nyeri pada otot atau permasalahan persedian, sesak napas, produksi dahak yang berlebihan, sakit tenggorokan, sakit kepala, kedinginan mual dan muntah, hidung tersebut dan lain sebagainya. Covid-19 ini juga dapat mematikan maka kasus kematian sejak munculnya Covid-19 ini sangat tinggi. Selanjutnya kebijakan yang harus 
dikeluarkan adalah pemberhentikan semua aktivitas yang berpeluang penyebaran covid-19 semakin menyebar (Rexadi 2019)(Konsumsi 2020). Negara Indonesia membuat kebijakan untuk memutuskan tali rantai Covid-19 yaitu dengan 14 hari dirumah saja, jika ingin keluar rumah maka seperlunya saja. Pemerintah membuat kebijakan PSBB ( pembatasan social berskala besar) dibuat untuk pencegahan covid-19, perbatasan tersebut meliputi perliburan sekolah dan tempat kerja, pembatasan kegiatan keagamaan, pembatasan kegiatan di tempat atau fasilitas umum, pembatasan kegiatan social dan budaya, pembatasan transportasi dan pembatasan yang lainnya menimbulkan kerumuman yang membuat Covid-19 cepat tersebar.

Adanya covid-19 ini mengakibatkan perusahan kecil atau perusahaan besar mengambil langkah untuk mengurangi jumlah pekerja atau karyawan sebagai upaya pencegahan penyebaran covid-19 sehingga terjadi PHK. Menurut data pemantauan ILO (International Labour Organization) karena adanya kebijakan warga untuk karantina penuh atau parsial saat ini sudah berdampak pada hampir 2,7 milliar pekerja, yang sudah mewakili sekitar 81 persen tenaga kerja dunia (Setiawati, Sariti, and Livana 2020). Sebelumnya permasalahan pengangguran telah menjadi permasalahan social yang sedang di pikirkan untuk keluar dari permasalahan tersebut. Bapak presiden tahun 2010 hingga 2024 memiki suatu ide untuk mengurangi pengangguran, program tersebut disebut dengan kartu pra kerja yang di tuju bagi penduduk Indonesia yang telah lulus SMA/SMK dan para mahasiswa yang lulus dari perguruan tinggi yang belum dapat pekerjaan,

Program kartu pra kerja di harapkan menjadi penopang ekonomi kala pandemi covid-19 saat ini, salah satu faktor yang menyebabkan tingginya angka pengangguran di negara Indonesia adalah terlampau banyak tenaga kerja yang di arahkan ke sektor formal maka saat mereka kehilangan 
pekerjaannya di sektor formal, mereka akan kelabakan dan tidak bisa berusaha untuk menciptakan pekerjaan sendiri di sektor informal. Pengangguran intelktual ini tidak dapat terlepas dari persoalan dunia Pendidikan yang tidak dapat menghasilkan tenaga kerja yang berkualitas dan kalah dengan tenaga asing dalam tuntutan pasar kerja (Dewita Hia 2015). Permasalahan tersebutlah yang menjadikan program kartu pra kerja sebagai solusi agar mereka yang pengangguran dapat membangun ekonomi kembali dengan bantuan yang di berikan sesuai dengan kebijakan yang berlaku. Dari hal tersebut maka makalah ini akan membahas mengenai kebijakan program kartu pra kerja dalam menggurangi tingkat pengangguran bagi penerima.

Program kartu pra kerja memberikan pelatihan bagi mereka yang lolos dalam tahap seleksi yang dilakukan secara online dikarena masa pandemi saat ini, pelatihan yang diberikan yaitu keterampilan yang bermanfaat seperti pelatihan membuat makanan, minuman, pelatihan otomotif, dan pelatihan yang lainnya sesuai keadaan yang dibutuhkan masa saat ini, pelatihan yang di ikuti dapat dilanjutkan untuk membuka lapangan kerja seperti memperdayakan keterampilan yang telah di ikuti dalam pelatihan program pra kerja. Tidak hanya itu saja mereka yang mengikuti pelatihan tersebut juga mendapatkan sertifikat. Artikel ini akan membahas mengenai kebijakan pemerintah dalam program pra kerja untuk mengurang pengangguran, metode penelitian yang dilakukan yaitu studi pustaka yaitu dengan mengumpulkan data yang diarhkan kepada sumber topik yang akan di bahas dan mengambil sumber dari jurnal dan segala referensi yang mendukung penelitian ini.

\section{Metode Penelitian}

Penelitian ini menggunakan metode penelitian kepustakaan (library research), yaitu penelitian dengan metode pengumpulan data pustaka atau penelitian yang obyek penelitiannya digali dengan beragam informasi 
kepustakaan seperti buku, ensiklopedi, jurnal ilmiah, koran, majalah dan dokumen yang lainnya (Nana Syaodih 2009). Penelitian kepustakaan merupakan suatu penelitian yang mendalami secara kritis suatu pengetahuan, gagasan, temuan yang terdapat dalam tubuh literatur berorientasi akademik (academic-oriented literature), serta merumuskan kontribusi teoritis dan metodologisnya mengenai topik tertentu. Penelitian ini berbentuk analisis deskriptif yaitu penjelas secara teratur data yang telah di peroleh, kemudian diberikan pemahaman agar dapat dipahami dengan baik bagi pembaca. Data yang digunakan dalam penelitian ini merupakan data sekunder yaitu sumber data yang di peroleh dari hasil penelitian yang telah di lakukan. Sumber data sekunder yang di maksud dalam penelitian ini berupa buku dan laporan ilmiah primer atau terdapat dalam artikel atau jurnal.

\section{Hasil dan Pembahasan}

Pengangguran merupakan permasalahan yang harus segera di atasi sesuai dengan program yang di janji oleh bapak presiden maka munculah suatu kebijakan mengenai program kartu pra kerja yang di arahkan untuk mengurangi pengangguran. Kebijakan merupakan suatu istilah Bahasa Indonesia yang memiliki kesamaan arti dengan Policy dalam Bahasa Yunani. Kata policy artinya kota, selanjutnya perkembangan dalam Bahasa latin menjadi politia (negara) dan pada akhirnya dalam Bahasa Inggris Policie berarti menangani masalah-masalah politik atau administrasi pemerintah (Dunn 2003). Sedangkan kebijakan social adalah salah satu bentuk dari kebijakan oublik. Kebijakan social merupakan ketetapan dari pemerintah yang di buat untuk merespon isu-isu yang bersifat public dalam mengatasi permasalahan social atau kebutuhan masyarakat banyak (NURSYAMSI 2018). Kebijakan sosial merujuk kepada apa yang dilakukan oleh pemerinta yang dapat menjadi upaya untuk meningkatkan kualitasi kehidupan melalui pemberian beragam 
tunjangan, pendapatan, pelayanan kemasyarakatan dan program-program tunjangan lainnya yang dapat bermafaat masyarakat.

Salah satu kebijakan sosial yang di berikan pemerintahan untuk mengurangi tingkat pengangguran di masa pandemi saat ini yaitu program kartu pra kerja sesuai dengan Peraturan presiden republic Indonesia nomor 36 tahun 2006 tentang pengembangan kompetensi kerja melalui program kartu pra kerja (Pemerintah Indonesia 2020). Program kartu pra kerja pertama kali di luncurkan pada 11 April 2020 yang awalnya memiliki tujuan untuk program pelatihan meningkatkan kompetensi dan daya saing bagi peserta yang mengikutinya. Namun, program ini di tambahkan pada skema bantuan sosial untuk mencegah peneurunan kesejahteraan masyarakat yang terdampak pandemic covid-19 yang sebelumnya tidak tercakup dalam skema bansos (Bantuan social) regular(2020, n.d.).

Pada masa pandemi covid-19 pendaftaran program pra kerja di lakukan secara daring dan pelatihan yang di berikan secara daring juga, program kartu pra kerja di tujukan untuk mereka yang pengangguran. Pengangguran adalah orang yang masuk kedalam Angkatan kerja (15 sampai 64 tahun) yang sedang mencari pekerjaan dan belum mendapatkannya, sedangkan mereka yang setengah pengangguran adalah bagian dari Angkatan kerja yang telah bekerja namun jam kerja di bawah jam normal atau kurang dari 35 jam seminggu, setengah pengangguran di bagi menjadi dua kelompok yaitu setengah pengangguran terpaksa adalah mereka yang bekerja di bawah jam kerja normal dan masih mencari pekerjaan atau dapat menerima pekerjaan yang lainnya, sedangkan setengah pengangguran sukarela adalah mereka yang bekerja dibawah jam kerja normal tetapi tidak mencari pekerjaan atau mereka tidak bersedia untuk menerima pekerjaan lainnya (Dewita Hia 2015). 
Bagi mereka yang lolos Program kartu pra kerja ini, selanjutnya penyaluran bantuan sosial ini dilakukan melalui transfer ke rekening bank atau dompet elektronik yang di miliki oleh peserta yang lulus program pra kerja tersebut. Namun, dengan metode tersebut terdapat celah yang memungkinkan penerima bantuan sosial tidak terdampak pandemic covid-19 secara ekonomi. Selanjutnya, kelompok masyarakat yang seharusnya menerima bantuan sosial seperti warga miskin, dan penduduk yang berpendidikan rendah tersebut justru tidak mendapatkan karena menghadapi masalah literasi dan teknologi saat ini. Selanjutnya peserta yang dapat mengikuti program pra kerja yaitu mereka yang terdampak covid seperti mereka yang mengalami PHK dalam pekerjaanya dapat mengikuti program kerja tersebut, dengan memenuhi persyaratan seperti warga Indonesia, minimal 18 tahun dan tidak sedang menempuh Pendidikan formal.

Manfaat yang di dapatkan untuk peserta yang mengikuti program kartu pra kerja yaitu, peserta mendapatkan pengetahuan yang membuat mereka semakin meningkat, selanjutnya materi pelatihan dapat di pratikkan secara langsung, materi pelatihan yang di berikan sangat relevan dengan pekerjaan saat ini dan materi pelatihan yang relevan dengan pekerjaan saat ini dan masa yang akan datang. Dari manfaat tersebut maka dapat di simpulkan bahwa pelatihan yang di ikuti bermanfaat karena peserta akan membuka usaha atau ingin meningkatkan usahanya untuk lebih baik saat ini dan pelatihan yang bermanfaat di ikuti peserta karena pernah bekerja atau memiliki cita-cita untuk bekerja dalam bidang yang berkaitan dengan pelatihan yang di ikuti.

Sasaran dalam program kartu pra kerja adalah pemberdayaan masyarakat yang lolos dalam seleksi yaitu dengan memilih pelatihan berdasarkan rencana kariernya untuk meningkatkan mompetensi dan produktivitas di bidang pekerjaan saat ini, selanjutnya peserta yang mengikuti 
program tersebut dan memiliki motivasi yang besar dan bersedia untuk menukarkan bantuan sosial yang mereka terima dengan kegiatan pelatihan yang lebih bermanfaat. Mereka juga menyadari bahwa adanya kebutuhan untuk meningkatkan kompetensi dan mempelajari keterempilan atau pengetahuan yang baru untuk mendapatkan pekerjaan yang lebih baik. Selanjutnya, sebagian besar peserta program pra kerja yang sesuai dengan sasaran pelatihan juga. Pemberdayaan masyarakat menurut payne yaitu untuk membantu klien memperoleh daya untuk mengambil keputusan dan menentukan tindakan yang akan dilakukan terkait dengan diri mereka, seperti mengurangi efek hambatan pribadi dan sosial (Adi 2012).

Pemberdayaan juga dipandang sebagai upaya untuk memapukan individu atau komunitas yang dimana diberikan wewenang atau kekuasaan yang memiliki tujuan untuk membuat masyarakat menjadi mandiri. Sedangkan menurut pendapat yang lain pemberdayaan merupakan konsep yang memiliki kaitannya dengan kekuasaan (Anwas 2013). Dalam program kartu pra kerja ini peserta dapat memanfaatkan insentif yang di berikan pemerintah untuk mengikuti pelatihan-pelatihan yang disediakan oleh pemerintah. Jenis pelatihan yang dapat di ikuti oleh mereka yang lolos dalam seleksi yaitu peletihan berupa keterampilan praktis jangka pendek yang sesuai dengan kebutuhan pasar kerja seperti pelatihan Teknik, informasi dan teknologi, pelatihan pertanian, pelatihan membuat makanan dan minuman, pelatihan lifestyle, pelatihan penjualan dan pemasaran, pelatihan perbankan dan jasa keuangan, pelatihan Bahasa, pelatihan perkantoran dan industry kreatif (Kementerian Koordinator Bidang Perekonomian Republik Indonesia 2020). Dalam pelatihan ini peserta juga nebdapatkan sertifikat pelatihan yang diakui baik pelatihan yang online ataupun pelatihan offline, peserta juga mendapatkan insentif yang ditransfer dalam tiga tahap. 
Pada situasi pendemi covid-19 saat ini, sasaran utama dalam program kartu pra kerja bukan lagi mencari kerja muda seperti yang direncanakan sebelumnya, namun para pekerja formal atau informal dan pelaku usaha mikro yang terdampak dan berkurangnya aktivitas ekonomi akibat pandemi covid-19 yaitu seperti mereka yang ter-PHK, dirumahkan atau mengalami penurunan penghasilan. Kebijakan ini merupakan respon cepat pemerintah untuk mengurangi keparahan atas krisis yang di sebabkan Covid-19/ efek dari program kebijakan ini, dalam tahun 2020, tidak lagi sepenuhnya untuk meningkatkan kompetensi pencari kerja atau tenaga kerja, tetapi sebagai solusi dalam melawan gelombang PHK yang semakin besar akibat krisis yang ditimbulkan oleh covid-19 ini.

Dalam penjalani program kartu prakerja ini mendapatkan tantangan dalam pelaksanaanya yaitu yang pertama yaitu pelatihan yang diberikan yaitu secara online atau offline, namun karena adanya kebijakan physical distancing dan PSBB, maka dari itu pelatihan yang dilakukan hanya diberikan secara online. Dengan demikian pilihan kursus bagi peserta menjadi terbata sesuai dengan platform yang di sediakan, sementara balai pelatihan daerah yang mungkin lebih sesuai dengan kebutuhanpeserta di setiap daerah belum dapat diakses. Tantangan yang kedua yaitu kebingungan bagi peserta yang telah mengikuti pelatihan bagaimana mana nasib mereka setelah lulus pelatihan tersebut. Selanjutnya yang ketiga yaitu karena program baru, tentu akan mengalami banyak temuan dalam pelaksanaannya yang membutuhkan perbaikan dan regulasi yang baik, terutama dalam tata kelola. Stigma bahwa program Kartu Prakerja lebih banyak menguntungkan platform digital dan Lembaga pelatihan kerja tentunya sulit untuk dihindari. Oleh karena itu, pengelolaan yang baik mulai dari hulu sampai ke hilir mutlak dilakukan untuk menjawab segala keraguan masyarakat. 
Kebijakan program kartu prakerja ini dapat membantu mengurangi pengangguran karena covid-19, perserta yang lolos dalam seleksi online maka dilanjutkan mengikuti pelatihan yang dapat bermanfaat bagi mereka dan mempratekkan pelatihan tersebut dalam bekerja serta dapat membuka lapangan pekerjaan bagi yang membutuhkan. Tujuan pemerintah dalam mempercepat realisasi kartu pra kerja dalam situasi pandemi COVID-19 merupakan salah satu upaya untuk mengelola dampak agar tidak semakin luas. Selanjutnya Pemberian dana insentif pelatihan, tidak berbeda halnya seperti bantuan langsung tunai, namun spesifik untuk para pencari kerja, individu yang terkena PHK, pelaku usaha yang gulung tikar, dan pekerja yang ingin meningkatkan ketrampilannya reaR(Abi Pratiwa Siregar \& Nadia Oktaviana 2020). Memperdayakan keterampilan untuk menciptakan lapangan kerja.

\section{Penutup}

Kebijakan sosial adalah suatu strategi-strategi, tindakan atau rencanarencana untuk mengatasi masalah sosial dan untuk memnuhi kebutuhan sosial. Kebijakan program kartu pra kerja yang di keluarkan pemerintah untuk pengembangan kompetensi kerja bagi mereka yang telah di PHK atau pengurangan penghasilan, namun juga dapat di ikuti mereka yang baru lulus sekolah SMA/SMK serta sarjana. Program kartu pra kerja memberikan insentif bagi mereka yang lolos dalam seleksi online. Intensif tersebut digunakan untuk membayar pelatihan yang telah disediakan. Selanjutnya peserta mengikuti pelatihan tersebut mendapatkan sertifikat dan dapat dimanfaatkan untuk kehidupan selanjutnya. Prohram pra kerja memberikan pelatihan untuk mengasah keterampilan peserta yang sesuai dengan keadaan saat ini dibutuhkan. Tujuan program kartu prakerja guna untuk mengurangi tingkat 
pengangguran dan di harapkan menjadi jalan untuk membuka lapangan pekerjaan.

\section{Daftar Pustaka}

2020. n.d. “Organisasi Kesehatan Dunia (WHO) Menetapkan COVID-19 Sebagai Pandemi Pada 11 Maret 2020. Pada 12 Maret 2020, Menteri Koordinator Bidang Perekonomian Mengatakan Bahwa Sistem Kartu Prakerja (KP) Masih Belum Selesai Dan Manajemen Pelaksananya Akan Ditetapkan."

Abi Pratiwa Siregar \& Nadia Oktaviana. 2020. “REALOKASI KARTU PRA KERJA DALAM MENDUKUNG INTENSIFIKASI SEKTOR PERTANIAN," no. 0274: 1-13. https://www.investindonesia.go.id/id/artikelinvestasi/detail/sektor-pertanian-di-indonesia.

Adi, I.R. 2012. Intervensi Komunitas Dan Pengembang Masyarakat (Sebagai Upaya Pemberdayaan Masyarakat). Jakarta: PT. Raja Grafindo Persada.

Anwas, E Oos M. 2013. Pemberdayaan Masyarakat Di Era Global. Bandung: Alfabeta.

Dewita Hia, Yulna. 2015. “Strategi Dan Kebijakan Pemerintah Dalam Menanggulangi Pengangguran." Economica 1 (2): 208-13. https://doi.org/10.22202/economica.2013.v1.i2.121.

Dunn, William N. 2003. Pengantar Analisis Kebijakan. Yogyakarta: Gajah Mada University press.

Kementerian Koordinator Bidang Perekonomian Republik Indonesia. 2020. "Kartu Pra Kerja."

Konsumsi, Harga Serta. 2020. “Dampak Pandemi Covid-19 Terhadap," 401-20. 
Nana Syaodih. 2009. Metode Penelitian Pendidikan. Bandung: PT. Remaja Rosdakarya.

NURSYAMSI. 2018. Kebijakan Sosial Pemerintah Terhadap Program BPJS Kesehatan (Study Kasus Di Masyarakat Desa Bontobiraeng Selatan Kecamatan Bontonompo Kabupaten Gowa). Makassar: Universitas Muhammadiyah Makassar.

Pemerintah Indonesia. 2020. “Peraturan Presiden No 36 Tahun 2020 Tentang Pengembangan Kompetensi Kerja Melalui Program Kartu Prakjerja," no. 022651.

Rexadi, Virda Ghesela. 2019. “Pengaruh Komunikasi Persuasif Suhay Salim Terhadap Keputusan Pembelianskincare Safi(Studi Pada Mahasiswi Ekonomi Islam Angkatan 2017 Fakultas Ekonomi Dan Bisnis Islam Universitas Islam Negeri Raden Fatah Palembang)." Hilos Tensados 1: 1476.

Setiawati, Laurika, Ike Sariti, and PH Livana. 2020. “Stigma Dan Perilaku Masyarakat Pada Pasien Positif Covid-19." Jurnal Gawat Darurat 2 (2): 95100. 